\title{
THE GREATER ROMAN HISTORIANS
}





\title{
THE GREATER ROMAN HISTORIANS
}

\author{
BY \\ M. L. W. LAISTNER
}

UNIVERSITY OF CALIFORNIA PRESS

BERKELEY AND LOS ANGELES

1963 


\section{UNIVERSITY OF CALIFORNIA PRESS}

BERKELEY AND LOS ANGELES

CALIFORNIA

\section{CAMBRIDGE UNIVERSITY PRESS}

LONDON, ENGLAND

COPYKIGHT, I947, BY

THE REGENTS OF THE UNIVERSITY OF CALITORNIA

ORIGINALLY PUBLISHED AS VOLUME TWENTY-ONE OF THE SATHER CL,ASSICAL LECTURES

SECOND PRINTING, I 963

(FIRST PAPER-BOUND EDITION) 